\title{
Geopolitinis įkaitas: Rusijos Federacijos Kaliningrado (Karaliaučiaus) srities atvejis
}

\begin{abstract}
Straipsnyje, atkreipiant dėmesị ị tam tikrą metodologinę stagnaciją kaliningradistikos fronte, yra grindžiama hipotezè, kad Maskva (Kremlius, metropolija, federalinis centras), siekdama išsaugoti suverenitetą srityje bei užtikrinti ryšio su ja nepertraukiamumą, pavertę šią eksklavinę provinciją geopolitiniu įkaitu - cesijos procese karo grobio pagrindu atitekusia teritorija, kuria siekiama ne tik išlaikyti (vidinis aspektas), bet ir priversti kitas valstybes arba tarptautines institucijas susilaikyti nuo bet kokio akto, kaip tiesioginès arba netiesioginès ịkaito išlaisvinimo sąlygos, ịvykdymo (išorinis aspektas).

Dèl konkrečios Kaliningrado padèties (Potsdamo šleifas, geografinè padètis, socialiniai ekonominiai veiksniai) Maskvai didesne reikšme gali turèti būtent vidinis aspektas, oficialiai „pridengiamas“ išoriniu. Formaliai Kremlius neprieštarauja ir net skatina, kad KS būtų traktuojama kaip specifinis, unikalus Rusijos regionas, tačiau praktikoje neleidžia jam ypatingai veikti. Taip siekiama sužadinti ir palaikyti srityje Stokholmo sindromą - kaliningradiečiai patys turi susitaikyti su eiline Rusijos Federacijos regiono padètimi, t.y. sutikti su tuo, kad visus sprendimus dèl KS funkcionavimo bei jos ateities priiminés Maskva, o KS kaip subjektui (veikejjui) - nebus leista veikti.
\end{abstract}

Šiandien pareikšti savo nuomonę Rusijos Federacijos Kaliningrado (Karaliaučiaus) srities klausimu tapo paskutiniu mados klyksmu tiek praktinėje tarptautinejje veikloje, tiek taikomuosiuose tarptautinių santykių ar užsienio politikos tyrimuose. Regis, net JAV prezidentas George Bush jaunesnysis, beje, Lietuvos ambasadoriaus Vašingtone dèka, žino, kad Karaliaučiaus sritis yra prie Baltijos jūros ir savo plotu maždaug lygi Maryland valstijai.

Tokia padėtis neturetu stebinti. Vien tai, kad diskusijos kaliningradistikos tema verda jau beveik penkiolika metų, rodo, kad Kaliningrado (Karaliaučiaus) sritis nèra eilinis Rusijos Federacijos regionas. Jo problematika po Śaltojo karo pabaigos daugiausia buvo siejama su klausimais, kuo bus Karaliaučiaus sritis ateityje, kokia vieta ir koks vaidmuo jai atiteks? Tirtinų klausimų lauką suformavo besikeičianti geopolitinè aplinka - Rusijos eksklavas atsidūrè Baltijos jūros regione sparčiai vykstančių euro-atlantinès integracijos procesų kelyje. Todèl buvo siekiama identifikuoti tikruosius Karaliaučiaus problemos parametrus saugumo, politikos ir ekonomikos srityse.

Prof., dr. Raimundas Lopata - humanitarinių mokslų daktaras, Vilniaus universiteto Tarptautiniu santykiu ir politikos mokslų instituto direktorius. Adresas: Vokiečių 10, 01130 Vilnius, tel. 8-5-2514130, e-paštas: raimundas.lopata@tspmi.vu.lt 
$\mathrm{XX}$ a. dešimtojo dešimtmečio pradžioje dẻmesio centre atsidūrẻ srities demilitarizacijos aspektai, galimi karinès grèsmès neutralizavimo būdai (nuo politinio tarptautinio spaudimo iki įvairių juridinio statuso pakeitimo planų). XX a. dešimtojo dešimtmečio viduryje regiono raidos perspektyvos nagrinètos per dviejų alternatyvų - karinio forposto ir ekonominio tilto tarp Rusijos ir Vakarų - prizmę. XX-XXI amžių sandūroje dienos šviesą išvydo studijos, glaudžiai susijusios su praktine tarptautine Kaliningrado aplinka. Kadangi šis laikotarpis sutapo su Lenkijos bei Lietuvos derybų su Europos Sajunga pradžia, todèl tiriamų klausimų ratą apibrèžè iš esmès Europos Sajungos plètra ir jos poveikis Rusijai apskritai ir konkrečiai Karaliaučiaus sričiai $^{1}$.

Apskritai šie etapai aiškiai atskleide domėjimosi „,atramos“ taškus: palaipsniui mažèjo lyginamasis karinių strateginių grèsmių analizės svoris, o vyrauti pradèjo „„̌velniojo“ saugumo aspektai: socialinis ekonominis srities atsilikimas, organizuotas nusikalstamumas, nelegali migracija, aplinkos užterštumas, susisiekimas su didžiaja Rusija ir pan. Be to, Karaliaučiaus sriti pradèta vertinti ne kaip vieną pagrindinių grèsmès visam regionui šaltinị, o kaip iššūki, atveriantị kokybiškai naujo tiek Baltijos jūros regiono, tiek Rusijos eksklavo raidos scenarijaus galimybes.

Tiesa, buvo abejojančių tokio scenarijaus galimumu. Pavyzdžiui, globalinės sumaišties koncepcijos šalininkai teigè, kad Rusijos tendencijų bei krypčių analizę komplikuoja ne tik po Šaltojo karo suirusi pasaulio geopolitinė sankloda, bet ir daugybė neprognozuojamų specifinių ekonominių, socialinių ir kultūrinių veiksnių, dèl kurių šios šalies transformacija ir tarptautinè adaptacija vyksta ypatingu būdu² . Kalbantys struktūrinès (konstruktyvistinès) geopolitikos terminais aiškino, kad Karaliaučiaus srities ateities miglotumą sąlygoja besiformuojančių geopolitinių tapatybių - Rusijos ir Europos Sajungos - nesugretinamumas ${ }^{3}$. Nepaisant skepsio, kaliningradistikoje įsivyravo postmodernistai, pasiūlę geopolitinị skirtingumą įveikti (slopinti) dialogu. Dialogas, pasak jų, turètų remtis naujais politinès erdvès organizavimo principais, kuriais remiasi ES daugiapakope valdymo logika ir kurie yra skleidžiami ES plètros: deteritorialumu, valstybių sienos reikšmès mažèjimu bei jų funkcijų kokybinių pasikeitimu, pasienio bendradarbiavimu bei tarptautiniu susiejamumu (ang. engagement), siekiant likviduoti skirtumus tarp kaimyninių regionų bei didinti regioninių veikèjų tarpusavio priklausomybę ${ }^{4}$.

Ši paradigma tapo populiari dèl Kaliningrad Puzzle metaforos. Lietuvoje ji prigijo Karaliaučiaus galvosūkio pavadinimu, nors patys metaforos autoriai ${ }^{5}$ turejjo galvoje konkretų galvosūkio variantą - dèlionę. Miglose skęstantis šviesesnès Kaliningrado ateities paveikslas (toks žaidimo tikslas), atitinkantis Kaliningrado gyven-

\footnotetext{
${ }^{1}$ Lopata R., „Naujausios kaliningradistikos apžvalga“, Politologija, 1, 2002, p. 96-104.

${ }^{2}$ Radžvilas V., Europos Sajungos pletra, JAV ir Lietuva, Šiaurès Atlanto erdve ir Lietuva, Vilnius: Eugrimas, 2001, p. 37-39; Aalto P., Structural Geopolitics in Europe: Constructing Geopolitical Subjectivity for the EU and Russia, University of Tampere, 2002.

${ }^{3}$ Aalto P., Structural Geopolitics in Europe: Constructing Geopolitical Subjectivity for the EU and Russia, Working Paper, University of Tampere, 2002, p. 26-27.

${ }^{4}$ Joenniemi P., Dewar S., Fairlie L. D., The Kaliningrad Puzzle, Karslkrona: The Aland Islands Peace Institute, 2000, p. 3-4, 26.

${ }^{5}$ Ten pat.
} 
tojų poreikius bei lūkesčius, atsižvelgiantis ị Rusijos - Europos santykių perspektyvą bei bendros europinès erdvės formavimo aspektus, turètų būti sudèliotas nūdieną identifikuotų problemų sprendiniais (konkretūs gamtos saugos projektai, keleivių tranzitas ir vizos, pasienio bendradarbiavimas ir t. t.).

Vis dèlto nepaisant intelektualių privalumų ir tam tikrų pasiekimų praktikoje besireiškiančiu ES - Rusijos susiejamumu iš esmès galinti ir nesibaigti dẻlionè i pašalị nustūmė principinị klausimą - kokị vaidmenị Karaliaučiaus sritis vaidina Rusijos užsienio ir vidaus politikoje?

\section{Diskusijos paraštèse}

Galima matyti akivaizdų pasikeitimą: anksčiau Karaliaučiaus srities atvejis buvo aptarinėjamas gana triukšmingai, o šiandien šiuo klausimu ramiai akademinejje aplinkoje keičiamasi nuomonèmis. Vieni, pavadinkime juos partikuliaristais, aiškina, kad vien tik geografinè šios Rusijos Federacijos srities padėtis pavertè ją unikaliu teritoriniu vienetu, reikalaujančiu specialaus dėmesio ${ }^{6}$. Jų argumentacijos arsenale ne tik specifinès geopolitinès situacijos faktas (euroatlantinè integracija, jos keliami iššǔkiai šalia esančiai valstybei bei jos teritorinei politinei anomalijai ${ }^{7}$, , bet ir komplikacijos, kylančios įvardinant tą teritorinę politinę anomaliją (anklavas, eksklavas, atskirtas regionas, tiesiog regionas ir pan. $\left.{ }^{8}\right)$. Jiems oponuoja generalistai, kurie, apeliuodami ị tokių teritorinių darinių analogus (Aliaska, Dancigas, Diego-Garsija, Gibraltaras, Makao, Vakarų Berlynas ir t.t.), stengiasi priminti, jog Karaliaučiaus atvejis nèra vienintelis ${ }^{9}$.

Toks apsikeitimas nuomonėmis iš pirmo žvilgsnio gali priminti apsišaudymą tuščiais šoviniais. Juk argi nėra pakankamai aiški eksklavo - valstybės teritorijos ar jos dalies, apsuptos kitų valstybių teritorija, bet turinčios jūros krantą - apibrèžtis? Gerai žinoma ir aksioma, kad kiekvienas atvejis plètojasi skirtinguose istoriniuose kontekstuose ir skiriasi konkrečiomis istorinèmis detalëmis. Kita vertus, ši konkreti partikuliaristų - generalistų diskusija išties verčia atkreipti dėmesį i neignoruotinas, t. y. istorijos patikrintas, bendras teritorinėms politinėms anomalijoms problemas, su kuriomis susiduria metropolija („,motininè valstybe்“, ang. home state) - eksklavas/anklavas - kaimyninè valstybė (angl. host state) arba valstybės, supančios teritorinę politinę anomaliją: jos administravimas ir saugumas, ekonominė padètis, čia gyvenančiujų identitetas, susisiekimas su atskirta teritorija. Metropolijos paprastai visomis priemonėmis siekia neutralizuoti grèsmes suverenitetui išlaikyti, įtvirtinant eksklavo/anklavo administravimą, nepažeidžiantį metropolijoje vyraujančių politinès-teritorinès kontrolès principų, ir užtikrinant efektyvų ryšį (susisiekimą) su juo

\footnotetext{
${ }^{6}$ Krickus R. J., The Kaliningrad Question, Lanham, Boulder, New York, Oxford: Rowman and Littlefield Publishers, 2002, p. 139.

${ }^{7}$ Terminas išpopuliarintas G. W. S. Robinsono // www.uta.edu/stillwell/išnašas.

${ }^{8}$ Nis S., „Kaliningrad - ne edinstvennyj anklav“, Pro et Contra, Moskva, 8 (1), 2003, p. 90-109; Holtom P., ,„Kaliningrad in 2001: From Periphery to Pilot Region“ in Holtom P., Tassinari F. Russian Participation in Baltic Sea Region Building: A Case Study of Kaliningrad, Gdansk, Berlin, 2002, p. 53; Joenniemi P., Prawitz J, eds., Kaliningrad: The European Amber Region, Aldershot, 1998, p. 265.

${ }^{9}$ Nis, (note 8) p. $90-106$.
} 
(„kaimyninès valstybės ignoravimo“ principas). Kaimyninès valstybės vaidmuo matomas iš jos reakcijos į metropolijos veiksmus, siekiant užtikrinti susisiekimą su eksklavu/anklavu. O pastarasis, ypač tais atvejais, kuomet jo ir metropolijos santykiu problematika pasiekia vadinamos didžiosios politikos lygmeni, patiria eksklavo/anklavo sindromą, jeigu tokio pobūdžio teritoriniai dariniai vertinami kaip specifiniai ar ypatingi, tačiau konkrečiomis priemonèmis nèra realizuojami specifiniai tokio darinio ir jame gyvenančiujų poreikiai, galu gale toks teritorinis darinys (jo gyventojai) praranda norą turèti specialų statusą ${ }^{10}$.

Plačiau neanalizuojant šios diskusijos, akivaizdu, kad metropolijos - kaimyninès valstybès - teritorinès politinès anomalijos trikampyje svarbiausias vaidmuo tenka būtent metropolijai, jos strategijai ir taktikai. Prisimenant klausimą - kokị vaidmenị Karaliaučiaus sritis vaidina Rusijos užsienio ir vidaus politikoje - pabrèžtina, kad konkrečiuose tyrimuose, nagrinėjančiuose metropolijos (Rusijos, Maskvos, Kremliaus, federalinio centro) veiksmus politinès teritorinès anomalijos (Rusijos Federacijos Karaliaučiaus srities) atžvilgiu, vyrauja metropolijos neapsisprendimo motyvas. Stai keli pavyzdžiai.

„Rusija dorai dar nesuformavo savo realios politikos ar požiūrio Kaliningrado atžvilgiu“, - prieš metus aiškino Sander Huisman, Europos Sajungos Saugumo studijų Instituto vizituojantis mokslo darbuotojas ${ }^{11}$.

Visai neseniai sprendžiant garsujị Rusijos piliečių tranzito ị/ǐs Kaliningrado srities klausimą Sergej Koršunov, Rusijos Federacijos Tarybos Tarptautinių reikalų komiteto ekspertas, vos ne į taktą S. Huisman nusistebejjo: „Maskva iki šiol nesuformulavo savo interesų Kaliningrado srities atžvilgiu, federalinis centras neturi jos geopolitinės rolès suvokimo, aiškių karinių interesų, ilgalaikès ekonominès strategijos, kurioje atsispindètų srities funkcijos pasidalijant darbą visos Rusijos mastu, užtikrinant užsienio prekybos ryšius, naudotinos priemonès jos raidai skatinti“"12.

Lietuvių politologai buvo į̌̌valgesni. Jų nuomone, Kremlius turi kelias strategijas Karaliaučiaus atžvilgiu: 1) Karaliaučius - karinio priešakinio posto arba ypatingo strateginio regiono sritis; 2) Karaliaučius - ekonominių reformų bandymų aikštė. Tačiau ir jiems iki šiol nèra aišku, kuri iš minètų strategijų poimperinès Rusijos politikoje dominuos ir bus realizuojama ${ }^{13}$. Suprantama, lietuvių mokslininkams daugiau rūpejjo kaimyninès valstybès, t. y. Lietuvos, vieta Rusijos projekcijose. Todèl nestebina ir minètos problemos sprendimo būdas. Buvo analizuojama, kaip Rusija stengèsi ir stengiasi išnaudoti susisiekimo (Rusijos Federacijos karinis tranzitas i i/ǐ̌ Kaliningrado srities per Lietuvos teritoriją, vizos ir civilinis tranzitas) klausimą, siekdama stabdyti Lietuvos euroatlantinès integracijos ir Lietuvos stojimo ị Europos Sajungą procesą. Šiame kontekste lietuviams atrodo, kad, ,atsižvelgiant ị Maskvos diplomatinio spaudimo šalims kandidatėms ir ES intensyvumą, sunku paneigti prie-

${ }^{10}$ Catudal H., The Exclave Problem of Western Europe, Alabama, 1979, p. 66; Holtom, (note 8) p. 53

${ }^{11}$ Huisman S., A New European Union policy for Kaliningrad, Paris: The European Union Institute for Security Studies, 2002, Occasional Papers, No. 3, p. 13.

${ }^{12}$ Koršunov S., „Kaliningrad kak problema Rosijsko - Evropejskoje partniorstva“, Meždunarodnaja žizn 1, 2003, p. 52-53.

${ }^{13}$ Sirutavičius V., Stanyte-Toločkienè I., „Rusijos Federacijos Kaliningrado srities strateginè reikšmë“, Lietuvos Metiné Strateginé Apžvalga, Vilnius, 2003, p. 176. 
laidą, jog Kaliningrado srities klausimas yra ne savaiminis tikslas, o tik Maskvos prie-

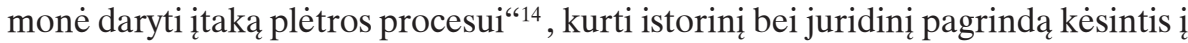
Baltijos valstybių suverenitetą ${ }^{15}$.

Pagaliau suomis Paami Aalto, atkreipęs dèmesị ir ị lietuvių pastangas paaiškinti, kodèl Kaliningrado korta atsidūre didžiojoje politikoje, trumpai drūtai reziumavo: Rusijos geostrategijoje Kaliningradas yra įrankis Rusijai tęsti didžiosios valstybès tradiciją ${ }^{16}$.

Mums atrodo, kad tai yra tik viena metropolijos (Maskvos) - eksklavo (Karaliaučiaus) santykių pusè. Spręsdama savo suvereniteto išsaugojimo ir ryšio užtikrinimo su Kaliningradu problemą, Maskvą šią sritį pavertė geopolitiniu įkaitu - cesijos procese karo grobio pagrindu atitekusia teritorija, kurią siekiama ne tik išlaikyti (vidinis aspektas), bet ir priversti kitas šalis arba tarptautines institucijas ịvykdyti arba susilaikyti nuo bet kokio akto, kaip tiesioginès arba netiesioginès įkaito išlaisvinimo sąlygos, îvykdymo (išorinis aspektas). Dèl konkrečios Karaliaučiaus srities situacijos (Potsdamo šleifas, geografinè padètis, socialiniai ekonominiai veiksniai) Maskvai didesnę reikšmę gali turèti būtent vidinis aspektas, oficialiai pridengiamas išoriniu. Formaliai Maskva neprieštarauja ir netgi skatina, kad Kaliningrado sritis būtų traktuojama kaip specifinis, unikalus Rusijos regionas, tačiau praktikoje neleidžia tam ypatingumui reikštis. Todèl siekiama sužadinti ir palaikyti srityje Stokholmo sindromą - kaliningradiečiai patys turi susitaikyti su ịprasto Rusijos regiono statusu, t. y. visus sprendimus dèl srities funkcionavimo ir ateities priims Maskva, o Kaliningrado sričiai - kaip subjektui (veikejjui) - nebus leista reikštis.

Straipsnyje pateikiami konkretūs atvejai, atskleidžiantys, kaip politinèje praktikoje funkcionuoja šis rusiškojo ịkaito mechanizmas: Karaliaučiaus eksklavas ịtraukiamas ị didžiają politiką siekiant sukurti jo ypatingumo aureolę, o „mažosios“ politikos lygmenyje, palaikant eksklave išskirtinumo viltis, tačiau neleidžiant joms praktiškai realizuotis, glaudžiai pririšti sriti prie Rusijos. Būtina turèti omenyje, kad čia priešpriešos tarp didžiosios ir, mažosios“ politikos nèra.

\section{Karaliaučius ir didžioji politika: NATO plètra}

Anatoli Liven, 1991 m. ir 1994 m. apsilankęs Kaliningrade, bene pirmasis pastebejjo groteskišką didžiosios ir „mažosios“ politikos samplaiką srityje: daugybė viena kitai prieštaraujančių srities raidos vizijų; susirūpinusios Vakarų kanceliarijos, siekiančios užkirsti kelią veiksniams, destabilizuojantiems regiono saugumą, kartu siekiančioms išsaugoti status quo; nepaprastai išaugęs kariškių skaičius ir irstantis karinis pramoninis kompleksas; liberalių pažiūrų karininkai, besiimantys privataus verslo ir balsuojantys už Boris Jelcin bei vadinamuosius reformatorius; konservatyvių kariškių bei rusų nacionalistų aljansai, pasiryžę išsaugoti Karaliaučių, kaip paskutinę karinę bazę Baltijos jūros pietuose ir paskutinį Antrojo pasaulinio karo laikų

\footnotetext{
${ }^{14}$ Ten pat, p. 200.

${ }^{15}$ Laurinavičius Č., Lopata R., Sirutavičius V., Military Transit of the Russian Federaytion Through the Territory of the Republic of Lithuania. Rusijos Federacijos karinis tranzitas per Lietuvos Respublikos teritorija, Vilnius, 2002, p. 72.

${ }^{16}$ Aalto, (note 2) p. 25.
} 
trofëju (kartu su Kurilais); pastangos iš naujo atrasti istoriją, vadinamus naujuosius prūsus, pervadinti miestą Kantogradu bei kiek galima daugiau pagaminti iškabų Koenigsberg; srityje populiari, kartais Maskvoje palaikoma, bet realiame gyvenime neveikianti laisvos prekybos zonos idejja; pagaliau gyvuojanti viltis, kad Vakarai suteiks pagalbą, plauksiančią į Kaliningradą vien dèl to, kad sritis netaptų destabilizacijos židiniu ${ }^{17}$.

Kiek vèliau Zbigniew Brzezinski tai pavadino vienu iš geostrateginès fantasmagorijos, istorinio ir strateginio sąmyšio (rus. zamešatelstvo) poimperinèje Rusijoje atspindžiu, kuomet vidinès transformacijos sunkumai, ekonominès politikos nesẻkmès sukūrè koliziją tarp realių Rusijos galimybių ir tebevyraujančių buvusios pasaulinės galios nuotaikų ${ }^{18}$. Būtent ši kolizija natūraliai tapo startine aikštele specifinèje geopolitinèje padètyje atsidūrusiai Rusijos Federacijos Karaliaučiaus sričiai sparčiai kilti ị aukštają politiką. Iš pradžių ji tapo tarptautinio politinio futurizmo objektu. Vèliau dèl savo specifinès geografinès padèties tapo taikiniu Rusijai bandant faktiškai spręsti šią koliziją. Rusija siekè dangstyti neatitikimą ypatingais santykiais su Vakarų valstybėmis (Andrej Kozyrev), visomis įmanomomis priemonėmis riboti jų galią (Jevgenij Primakov), rinktis kompromisinę šių strateginių orientacijų liniją (Vladimir Putin) ${ }^{19}$.

Pastebėtina, kad tarptautinis politinis futurizmas Karaliaučiaus atžvilgiu pradejo blèsti 1993 m. pab. - 1994 m. pr., kai energingu provakariečiu vadinamas Rusijos užsienio reikalų ministras A. Kozyrev pareiškè, kad Rusija „išlaikys savo karini buvimą regionuose, šimtmečiais priklaususiais jos ịtakos sferai“". Be to, vyriausybès laikraštis „Izvestija“? pasiūle atkreipti dėmesị i tą aplinkybę, kad Rusijai pavyko išsaugoti beveik trisdešimt limitrofų, kurie nuo Kaliningrado iki Kurilų sudaro liniją, iš esmés atitinkančią buvusios SSSR teritoriją. Būtent tada buvo pradèta realiau svarstyti ne tik šių limitrofų instrumentiškumą poimperinės Rusijos identitetui vystyti, bet ir klausimą, ką naujame geopolitiniame kontekste reiškia metropolijos bandymai išsaugoti didžiosios valstybès stereotipą: ar Rusija laukia patogaus momento išsiplètoti, ar ruošiasi išgyventi beveik totalinės apgulties sąlygomis? ${ }^{20}$.

Konkrečiu Karaliaučiaus atveju išpopuliarejo interpretacija, paremta galios pusiausvyros (balansavimo) koncepcija: metropolija naudoja sritį kaip veiksnị, atgrasinantị NATO nuo plètros Rytų kryptimi ${ }^{21}$.

Išties pirmojo NATO plètros etapu XX a. dešimtojo dešimtmečio pr. Kaliningradas atsidūrè priešakinèse rusų politinio elito antinatinès argumentacijos linijose. Buvo ne tik primenama, kad Vakarai už Vokietijos suvienijimą dar Prezidentui Michail Gorbačiov žadejjo neplèsti Šiaurès Atlanto sutarties organizacijos ar kad tokia plètra kelia pavojus gležnai demokratijai Rusijoje išsilaikyti, bet ir bauginama nauja geležine siena, kurioje ypač žiojès Kaliningrado ambrazūra.

${ }^{17}$ Lieven A., Pabaltijo revoliucija, Vilnius, 1995, p. 218-223.

18 Bžezinski Z., Velikaja šachmatnaja doska, Moskva, 1999, p. 118.

${ }^{19}$ Laurinavičius Č., „Rusijos užsienio politika po Rugsėjo 11-osios“, Lietuvos Metine Strateginè Apžvalga, Vilnius, 2003, p. 159-161.

${ }^{20}$ Bžezinski, (note 18) p. 130; Lopata R., Laurinavičius M., Tarptautine politika: komentarai ir interpretacijos.Vilnius, 2002, p. 252.

${ }^{21}$ Sirutavičius, Stanytė-Toločkienè, (note 13) p. 176. 
Tam tikrais atvejais rusų retorika priminè Nikita Chruščiov laikų frazę: „Berlynas - tai Vakarų séklidès. Kai noriu, kad Vakarai klyktų, suspaudžiu Berlyną". Dar 1993 m. rugpjūčio mèn. Boris Jelcin ėmèsi ,šaltaja taika“ grasinti ị NATO žengiančiai Lenkijai, Lietuvai buvo mėginama ịpiršti karinị koridorių, o Karaliaučių paversti kariniu strateginiu bastionu. 1994 m. kovo mèn. Karaliaučiuje apsilankęs Rusijos Gynybos ministras Pavel Gračiov paskelbè, kad sritis tapo specialiu rusų Baltijos karinio laivyno vado vadovaujamu gynybiniu rajonu, tiesiogiai pavaldžiu Gynybos ministerijai ir Generaliniam štabui. Rusijos generalitetas ir kariniai analitikai siūlè keisti Rusijos karinę doktriną ir atsisakyti principo pirmajai nenaudoti branduolinio ginklo, grasino dislokuoti srityje taktinį branduolinį ginklą (pastebètina, kad čia nuolatos vykdavo kariniai manevrai22 ). 1994 m. pab. admirolas Vladimir Jegorov situaciją aiškino labai paprastai: siekiama išsaugoti Rusijos teritorinị integralumą, užkirsti kelią karinès pusiausvyros iškraipymams, garantuoti susisiekimą su Rusija bei išsaugoti ekonominị regiono stabilumą. Tolimesnè srities raida, pasak admirolo, priklausys nuo kaimyninių valstybiu elgsenos palaikant abipusị saugumą ${ }^{23}$.

Tačiau tuo pačiu metu srities karinis potencialas buvo mažinamas ${ }^{24}$, o Maskvos diplomatai beveik atvirai siūle Lenkijai ir Baltijos valstybėms atsisakyti jungtis ị Šiaurès Atlanto sutarties organizaciją už Karaliaučiaus krašto demilitarizavimą ${ }^{25}$.

NATO pirmoji plètros banga, kaip žinoma, nebuvo sustabdyta, nebuvo nubrèžtos ir aiškios Kaliningrado srities demilitarizacijos ribos, tačiau 1997 m. buvo įsteigta NATO ir Rusijos Nuolatinė jungtinè taryba, suteikusi Maskvai tam tikru vilčių būti ịtrauktai ị Vakarų strateginių klausimų prièmimo procesą ${ }^{26}$.

Kita vertus, vadinamoje Vakarų saugumo bendruomenëje kilo gana audringos diskusijos dẻl tikrosios, autentiškos, Kaliningrado karinės strateginės reikšmės.

Iki šiol yra svarstoma, kokiais motyvais vadovavosi tarptautinio saugumo analitikai bei praktikai, pašaipiai vertinę Kaliningrado - forposto ideją, ir ekspertai, traktavę ją labai rimtai. Iki šiol yra prisimenama, kaip JAV Valstybès sekretoriaus pavaduotojas Richard Holbrooke neužmiršdavo pabrèžti, kad Kaliningrado srities klausimas atrodo komplikuotas tik tada, kai i ji žvelgiama pro geografo akinius, nors šiaip jau jis yra tik Vakarų - Rusijos santykių dalis. Iki šiol neužmiršta ir žymių RAND korporacijos analitikų Ronald D. Asmus ir Robert C. Niurick išvada, kad Karaliaučiaus sritis yra strateginis karinis avanpostas, kuriame sutelkta milžiniška Rusijos karinė galia, ypač Baltijos valstybes paverčianti specialiu atveju ${ }^{27}$. Tuomet Baltijos valstybėse ir ypač Lietuvoje abi nuomonès buvo sutiktos jautriai, kadangi

\footnotetext{
${ }^{22}$ Oldberg I., Kaliningrad: Russian Exclave, European Ebclave, Stokhom, 2001, p.15.

${ }_{23}$ Jegorov V., Cooperative Security in Northern Europe, Ideas on Cooperatvive Security in the Baltic Sea Region, Helsinki, 1995, p. 130-131.

${ }^{24}$ Per 1993-1998 m. puolamujuc malūnsparnių skaičius sumažèjo nuo 48 iki 42, naikintuvų nuo 35 iki 28, povandeninių laivų nuo 15 iki 2, fregatų nuo 24 iki 4, patrulinių pasienio laivų nuo 140 iki 30. Šiuo laikotarpiu išaugo tik tankų skaičius - nuo 620 iki 1000. Plačiau žr.: Sirutavičius, StanytėToločkienè, (note 13) p. 177. Pastebėtina, kad toks padidejimas iš esmès buvo siejamas su finansinių lěšų trūkumu pergabenti juos i „,didžiają Rusiją“.

${ }^{25}$ Landsbergis V., Karaliaučius ir Lietuva, Vilnius, 2003, p. 132; Krickus, (note 6) p. 72.

${ }^{26}$ Lopata R., Vitkus G., sudar., NATO: vakar, šiandien, rytoj, Vilnius, 1999, p. 75.

${ }^{27}$ Laurinavičius, Lopata, Sirutavičius, (note 15) p. 47-49; Krickus, (note 6) p. 56.
} 
nebuvo, regis, apsispręsta, ar specialus atvejis yra privalumas, ar, priešingai, trūkumas. Tačiau tame ekspertinių svarstymų kontekste ypač palankiai buvo sutikta JAV respublikono Christopher Cox rezoliucija, iš esmès mainais už Karaliaučiaus demilitarizaciją siūlantį JAV ekonominę paramą Rusijos Kaliningradui ${ }^{28}$.

Nepriklausomai nuo lietuviškų vertinimų, tarptautiniame saugumo diskurse Kaliningrado veiksnys formaliai tapo vertinamas kaip Vakaru (NATO) ir Rusijos santykių problema, nors akivaizdžiai šis Rusijos Federacijos regionas ėmè atlikti ne tiek sulaikymo, kiek ịkeisto daikto funkciją Rytų - Vakarų strateginiuose mainuose, paremtuose atgrasinimo (sulaikymo) - nuraminimo (ang. appeasement) taktika. Beje, šiame kontekste ypač iškalbingai atrodẻ kai kurių Kaliningrado srities Dūmos deputatų intervencija 1997 m. spalio mèn. susieti pasirašomą Lietuvos - Rusijos sutartị dèl valstybinès sienos su rusų karinio tranzito per Lietuvos teritoriją i i/iš Kaliningrado srities klausimu ${ }^{29}$.

Situacija pasikartojo vykstant debatams dèl antrosios NATO plètros bangos ir praktinès jos sklaidos. Pasinaudodama įvykiais Kosove, 1999 m. Maskva sugriežtino tradicinę antinatinę retoriką, išaldè dalyvavimą NATO - Rusijos Nuolatinèje jungtinèje taryboje, ėmè spartinti nuo $1996 \mathrm{~m}$. puoselètus Rusijos - Baltarusijos sajunginès valstybès ịkūrimo planus, o atgimusiam balansavimui ịrodyti Karaliaučiaus srityje surengè bendrus rusų - baltarusių grandiozinius karinius manevrus „Vakarai - 99“ (,Zapad-99“). Manevruose buvo repetuota deeskalacijos misija, imituojant taktinio branduolinio ginklo panaudojimą NATO agresijai atremti.

2000 m. liepos mẻn. į Baltijską Karinio laivyno dienos švęsti atvykęs Prezidentas Vladimir Putin garsiai pareiške apie šio limitrofo remilitarizaciją, pabrèždamas, kad rusų Baltijos jūrų laivynui, atsižvelgiant ị Rusijos strateginius interesus visose jūrose ir vandenynuose, bus skiriamas ypatingas dèmesys ${ }^{30}$. Tai, kad Prezidento žodžiai nėra tušti, iliustravo ne tik visas paketas Kremliuje priimtų dokumentų dèl nacionalinio saugumo, užsienio politikos, karinès doktrinos bei karinès reformos, bet ir $2000 \mathrm{~m}$. lapkričio mèn. Karaliaučiuje įvykęs išvažiuojamasis Federalinio saugumo tarnybos kolegijos posėdis, skambiai pavadintas „Dèl padèties ir priemonių pasipriešinti grèsmėms saugumui ir Rusijos Federacijos suverenitetui Kaliningrado srityje“. Posédyje, be kita ko, buvo pažymèta, kad gali „kilti ịtampa tuo atveju, jei Lietuva ịstos į NATO, todèl sričiai jau šiandien reikia pradėti ruoštis“"31.

Tarsi patvirtinant Maskvos posūkį i Karaliaučiaus atgaivinimą karinio forposto vaidmenyje $2001 \mathrm{~m}$. pradžioje pasirode pranešimų, esą Rusija, vykdydama savo grasinimą visomis išgalemis priešintis naujajai NATO plètrai ị Rytus, dislokuoja šiame krašte taktinị branduolini ginklą 32 . Tuo pačiu metu paplito gandai dèl galimo Vokietijos ir Rusijos sandėrio Karaliaučiaus sąskaita, o 2001 m. pavasarį išryškejjo ir realus Maskvos spaudimas politine sutartimi įteisinti Rusijos karinị tranzitą per Lietuvos teritoriją i $/$ /iš Kaliningrado sritị. Kovo mèn. pab., prieš prasidedant Lietuvos

${ }^{28}$ Landsbergis, (note 25) p. 136-139.

${ }^{29}$ Krickus, (note 6) p. 63.

${ }^{30}$ Oldberg, (note 22) p. 16.

${ }^{31}$ Lopata R., „Santykiai su Kaliningrado sritimi euroatlantinės integracijos kontekste“, Pranešimas

Lietuvos užsienio politikos tarybos posedyje, Vilnius, 2001 m. gruodžio 21 d., p. 2.

${ }^{32}$ Lopata, Laurinavičius, (note 20) p. 222-224. 
Prezidento Valdo Adamkaus vizitui Rusijos Federacijoje, šis spaudimas pasiekė apogejuų, virsdamas antilietuviška - antinatine isterija, beje, lydima paskleistų gandų, jog rusai siūlysią lietuviams vos ne pusę Kaliningrado srities mainais už Lietuvos atsisakymą stoti į NATO arba neleisią V. Adamkui po Maskvos apsilankyti Kaliningra$\mathrm{de}^{33}$.

Nors jau vizito metu galima buvo įžvelgti, kad, Lietuvai atlaikius spaudimą, Rusijos vadovybė linkusi susitaikyti su Baltijos valstybių naryste Aljanse ${ }^{34}$, kietosios linijos su Vakarais šalininkai, vadinami vanagai, ir toliau reiške nepasitenkinimą. Maskvoje pagausėjo pareiškimų, siejančių NATO plètrą su konvencinès ginkluotès apribojimo sutarties išplètimu Rytų Pabaltijyje bei Rusijos dalyvavimu antiteroristinëje koalicijoje, o Kaliningrade neseniai paskirtas Baltijos karinio laivyno vadas Vladimir Valujev netgi grasino, esą jam nereikès branduolinio ginklo kam nors ,i vietą pastatyti“, nes aplink Karaliaučiu yra ịprastine ginkluote pažeidžiamos 47 atominès elektrinè ${ }^{35}$. Nepatogioje padètyje atsidūrè ne tik buvęs laivyno vadas, dabartinis Kaliningrado srities gubernatorius V. Jegorov, bet ir kai kurie srities Dūmos deputatai su jos pirmininku Vladimir Nikitin priešakyje, iki tol aiškinę (beje, net ir po susitikimų su šalies Prezidentu), kad NATO plètra nekelia grèsmès regionui. Aukščiausieji srities pareigūnai pradejo primygtinai siūlyti atidèti Rusijos - Lietuvos sienos sutarties ratifikavimą ${ }^{36}$.

Tiesa, tai reikalo esmès nekeitè. NATO plètros antrajai bangai ritantis į priekị, 2002 m. gegužès 27 d. buvo įkurta bendra NATO ir Rusijos taryba. Nors joje Rusija ir neigijo veto teisès sprendžiant Aljanso plètros ar jo narių saugumo klausimus, tačiau Maskva galejjo pasigirti sèdinti kartu su NATO šalių atstovais pagal vadinamą 20-ą formulę. Panašu, kad sulaikymo - nuraminimo kontekste Kremlius ir vèl akivaizdžiai pademonstravo, kad elgiasi su Kaliningradu kaip su įkaitu.

\section{Karaliaučius ir „mažoji“ politika: laisvoji (ypatingoji) ekonominè zona}

Kartą viešint Karaliaučiuje teko išgirsti įtakingo vietinio politiko pastabą: „Šiandien Rusijos Federacijos Kaliningrado sritis yra graži, bet akla mergužèle““. Tada dèl grožio nesiginčijome, nes buvo pasiūlyta kitokia alegorija - pasaka apie Miegančiają gražuolę. Potekstè buvo tarsi nesunkiai suvokiama: lengviau pažadinti miegantị, nei tikètis, kad aklas praregès. Regis, tuo metu mes, lietuviai ir rusai, nesupratome vieni kitų. Mums atrodè, kad kaliningradiečiai iš esmès ignoruoja visas Lietuvos ir apskritai Vakarų pastangas juos pažadinti, t. y. paskatinti galvoti, jog srities ateitis pirmiausia priklauso nuo vietinių pastangu. Mes nesupratome, kad tos pastangos buvo dedamos, ką jau klausti, kodèl jos buvo žlugdomos.

Šiandien neslepiama, kad tonąžemajai politikai suteikè dar $1989 \mathrm{~m}$. prasidejję svarstymai tarp Kaliningrado ir Maskvos dẻl galimybių sričiai funkcionuoti po Lie-

\footnotetext{
${ }^{33}$ Laurinavičius, (note 19) p. 164; Lopata, Laurinavičius, (note 20) p. 236.

${ }^{34}$ Laurinavičius, (note 19) p. 164.

35 „Vsegda gotovy“, Itogi 20 (258), 2001 m. gegužès 30 d.; (http://Itogi.ru).

${ }^{36}$ Lopata, Laurinavičius, (note 20) p. 231.
} 
tuvos atsiskyrimo nuo SSSR. Būtent tada regionui buvo suteikta vilčiu, kad jos išsigelbèjimo ratas - statuso pakèlimas (respublika RSFSR sudètyje ${ }^{37}$ ) bei pliuralizmas ekonominèje raidoje. RSFSR Ministrų tarybos pirmininko V. Vorotnikov vadovaujama darbo grupè srities statuso nesvarstė. Maskva ruošèsi užkirsti kelią populiarẻjančiai tuometinèje SSSR suverenizacijos idejjai ir pasiūlyti naują regioninès politikos koncepciją - regioninę ūkiskaitą. Pastaroji, beje, vadinta tiek laisvaja verslininkyste, tiek laisvaja ekonomine zona, buvo patraukli ir daugeliui to meto regionų lyderių, kadangi numatė ne tik didesnị jų savarankiškumą sprendžiant ūkinius klausimus, užsienio kapitalo dalyvavimą steigiant bendras įmones, bet ir perdavimą i jų rankas vadinamojo sajunginio pavaldumo objektų valdymą. $1990 \mathrm{~m}$. liepos - 1991 m. rugsèjo mèn. RSFSR Aukščiausioji Taryba patvirtino specialios ekonominès zonos statusą vienuolikai Rusijos regionų ( $7 \%$ teritorijos su $13 \%$ Rusijos gyventojų). Metų pabaigoje gauti tokị statusą išreiškè norą dar apie 150 regionų. Tačiau 1991 m. pab. - 1992 m. pr., Maskvai nusprendus igyvendinti atviros ekonomikos koncepciją, naujieji pretendentai buvo išbraukti iš sąrašo, o tarp senujjų užvire gana atkakli konkurencinè kova.

Būtent tuo laikotarpiu Sankt Peterburgo meras Anatolij Sobčiak įtikino Kremlių nedidinti iš Centrinès Europos išvedamos sovietinès kariuomenès sąskaita karinių pajègumų Leningrado srityje ${ }^{38}$, siūlant juos, ypač karinio laivyno pajègas, dislokuoti Kaliningrado srityje. Federalinis centras, tarsi teisindamasis, toliau priiminejo i̊statyminius aktus, aiškinančius $1991 \mathrm{~m}$. birželio 3 d. RSFSR Aukščiausiosios Tarybos pirmininko potvarkị „Dèl ūkinio teisinio laisvos ekonominès zonos „Jantar“ Kaliningrado srityje statuso“: 1991 m. rugsejjo 25 d. RSFSR Ministrų Taryba patvirtino „Memorandumą dèl Laisvosios ekonominès zonos (LEZ) „Jantar“, o $1992 \mathrm{~m}$. gruodžio mèn. Rusijos Federacijos Prezidentas paskelbè ịsaką „Dẻl išorinių ekonominių sąlygų sudarymo Kaliningrado srities raidai“. Šiuose aktuose buvo užfiksuotos tos mokestinès išimtys bei skirtinos investicijos infrastruktūrai ir žemès ūkiui vystyti, kurios turejo, manyta, paskatinti socialinę ekonominę regiono raidą ir pabrèžti regiono išskirtinumą. Beje, 1992 m. pab. Rusijos Valstybès Dūma sutiko svarstyti ir Kaliningrade paruoštą įstatymą „Dèl Kaliningrado srities statuso“39 , o tuometinis srities gubernatorius Jurij Matočkin netgi prabilo apie galimybę Kaliningradui per dešimt metų tapti Baltijos Honkongu.

Tačiau jau 1993 m. liepos 2 d., priẻmus išimtis anuliuojantị federalinị įstatymą „Dẻl muitų tarifų“, LEZ Karaliaučiaus srityje nustojo galioti. Nors 1993 m. pab. buvo paskelbtas Rusijos Prezidento ịsakas „Dèl Kaliningrado srities“, 1994 m. gegužès mèn. vyriausybės potvarkis „Dèl neatidèliotinų priemonių stabilizuojant Kaliningrado srityje ekonominę padètį“, o 1994 m. spalio 12 d. Rusijos Saugumo Tarybos sprendimas „Dèl LEZ vystymo Kaliningrado srityje“, iš esmès laisvoji ekonominè zona nefunkcionavo. $1995 \mathrm{~m}$. kovo 6 d. naujas Prezidento įsakas dèl taikytinų išimčių LEZ „Jantar“ panaikinimo buvo tik formalumas. Jau 1994 m. Rusijos Valstybès

\footnotetext{
${ }^{37}$ Kargopolov S., Gorodilov A., Kulikov A., Gomin A., XXI viek: Svobodnaja zona i osobyj status, Kaliningrad, 2001, p. 77.

${ }^{38}$ Krickus, (note 6) p. 58.

${ }^{39}$ Clopeckij A., Fiodorov G., Kaliningradskaja oblast: region sotrudnichestva, Kaliningrad, 2000, p. 331.
} 
Dūmai pateiktas ịstatymo projektas „Dèl Kaliningrado srities statuso pakẻlimo“virto įstatymu „Dèl Rusijos Federacijos suvereniteto stiprinimo Kaliningrado srities teritorijoje“, buvo sugriežtintos muitinès procedūros, sustiprinta sienų kontrolè, anuliuoti prekybos susitarimai, sudaryti tarp regiono ir kitų šalių. Tuoj po gynybos ministro P. Gračiov Karaliaučiuje apsilankęs Rusijos ministro pirmininko pavaduotojas Sergej Šachraj atvirai užsipuolè vietinius separatistus, palaikančius Vakarų ekspansiją, ir pareiškė, kad srities ateitị visų pirma lems visos šalies strateginiai intere$\mathrm{sai}^{40}$.

Pasak pačių kaliningradiečių, 1995 m. pabaigoje trapų politinį balansą tarp Karaliaučiaus ir Maskvos interesų šiaip taip pavyko įtvirtinti federaliniu įstatymu „Dèl ypatingos ekonominès zonos (YEZ) Kaliningrado srityje“, kuriam 1996 m. sausio 5 d. pritarè Federacijos Taryba, o sausio 22 d. pasiraše ir B. Jelcin ${ }^{41}$. Ta proga Rusijos Federacijos Tarybos pirmininkas Vladimir Šumeiko netgi užsiminè apie Karaliaučiaus autonomijos galybę, išreiške viltị, kad sritis gali tapti tarptautinių kongresų centru, bevize turistine zona ir apskritai liberalios ekonomikos eksperimentu. Tačiau federalinis ịstatymas laukiamo efekto nedavè. 1996 m. pradžioje pasirašyta „Kaliningrado srities ir Rusijos Federacijos sutartis“ bei sudarytas „Rusijos Federacijos vyriausybès ir Kaliningrado srities administracijos susitarimas dèl kompetencijų pasidalijimo“, kaip vèliau paaiškẻjo, jokių ypatingų teisių sričiai nesuteikè $\dot{e}^{42}$. Nors $1997 \mathrm{~m}$. rugsėjo $29 \mathrm{~d}$. buvo paskelbta „Federalinè tikslinè ypatingos ekonominès zonos Kaliningrado srityje 1998 - 2005 m. raidos programa“, srities Dūma prièmė i̊statymą „Dèl vietinių laisvų ekonominių zonų Kaliningrado srityje“, o 1998 m. gegužès mèn. - „Regioninę socialinès ekonominès Kaliningrado srities raidos programą", susigrąžintos privilegijos tebuvo tik iliuzijos. Tuometinei srities administracijai su gubernatoriumi Leonid Gorbenko priešakyje beliko apeliuoti į Gibraltaro pavyzdị ir guostis, esą ateityje bus įmanoma suderinti karinio forposto bei ekonominių reformų bandymų aikštelès funkcijas ${ }^{43}$.

Šiandien netrūksta aiškinimų, esą laisvos, o vèliau ypatingos ekonominès zonos likimą sąlygojo prieštaringas Rusijos federalizacijos procesas, regioninès politikos koncepcijos bei atitinkamų finansinių resursų stokos Maskvoje sąlygota įstatyminè tokių zonų veiklą reguliuojančiu intervencijų gausa (daugiau kaip dešimt dažnai vienas kitam prieštaraujančiu įstatyminių ar poịstatyminių aktų vien 1992 - 1996 m.), sudėtinga, įvairių krizių krečiama (pavyzdžiui, $1998 \mathrm{~m}$. vadinamoji finansinė krizè) socialinė ekonominè situacija Rusijos Federacijoje, menki Kaliningrado srities politinio elito administravimo gebejimai, aukštas korupcijos lygis, visuomenès inertiškumas ir t.t. ${ }^{44}$ Visa tai neblogai paaiškina laisvosios (ypatingosios) ekonominės zonos likimą Karaliaučiaus srityje. Tačiau kartu negalima nepastebėti ir dar keleto aplinkybių.

Atidžiau susipažinus su aktais, reguliuodavusiais LEZ(YEZ) veiklą, ar programomis, skirtomis joms igyvendinti, akivaizdu, kad pagrindiniu politiniu ir finan-

\footnotetext{
${ }^{40}$ Oldberg, (note 22) p. 55.

${ }^{41}$ Gorodilov A., Kozlov S., Geopolitika, Kaliningrad, 2003, p. 61.

${ }^{42}$ Clopeckij, Fiodorov, (note 39) p. 337.

${ }^{43}$ Oldberg, (note 22) p. 18; Clopeckij, Fiodorov, (note 39) p. 364-368.

${ }^{44}$ Sirutavičius, Stanytè-Toločkienè, (note 13) p. 176.
} 
savimo vertu prioritetu buvo skelbiamas siekis ịtvirtinti Kaliningrado srityje Rusijos suverenitetą ir panaudoti srities teritoriją garantuojant šalies gynybinį pajëgumą. Praktikoje tai reiškè, kad didžioji dalis įvairiose programose numatytų lëšų plaukẻ kaip subsidijos kariniam pramoniniam kompleksui išlaikyti ${ }^{45}$. Kita vertus, pačių kaliningradiečių vertinimu, nepaisant ịstatyminès laisvos (ypatingos) ekonominès zonos bazės kaitos, jos sukeltų komplikacijų ir paralyžių, finansavimo prioriteto vienašališskumo, laisvos (ypatingos) ekonominès zonos idèja vis dèlto paskatino struktūrines permainas srities ekonomikoje, suvaidino pozityvų vaidmenį skatinant bendro kapitalo įmonių steigimąsi, politiškai tapo visuomenę vienijančia idèja ${ }^{46}$ ir pagrindu harmonizuojant srities bei federalinio centro interesus ${ }^{47}$.

Problema yra ta, aiškino kaliningradiečiai, kad Maskva, ,viena ranka dovanodama vieną ar kitą dekretą, kita ranka jį atimdavo". Kitaip tariant, federalinis centras, keldamas viltis suteikti Kaliningrado sričiai ypatingumą, reikalavo visus veiksmus derinti su juo. Tai savo ruožtu didino įtampą tarp srities ir centro, nepasitikẻjimą juo, galų gale verte prisipažinti, jog srities „ypatingumas yra jos uždarumas“, o terminą zona reikia suprasti pačia primityviausia žodžio prasme $e^{48}$.

\section{ES plètra ir Karaliaučius: didžiosios ir „mažosios“ politikos samplaika}

ES plètra į Rytus dar labiau paryškino Karaliaučiaus srities, kaip Maskvos ịkaito, vaidmenị. Visų pirma ji apibrěžiama kaip sritis, kurioje dẻl Maskvos manipuliacijų praktinèje politikoje palaikomos tiek galimos jos atsivèrimo, tiek galimos jos tolimesnio izoliavimo tendencijos. İ šį žaidimą, beje, buvo įtraukta Europos Komisija ir į ES besirengiančios įstoti kaimyninès valstybès - Lenkija ir Lietuva.

Šiandien iš esmès visuotinai pripažįstama, jog ypač Vilniaus aktyvūs mėginimai ịgyvendinti mintị, kad Rusijos Federacijos Kaliningrado sritis nusipelno ypatingo dėmesio, leidžiančio regioną paversti Vakarų ir Rytų ryšių plètotės pavyzdžiu, nemažai prisidejjo prie Kaliningrado klausimo iškilimo Rusijos ir ES darbotvarkèje. Vilnius, žinoma, siekdamas savųjų nacionalinių interesų realizavimo, pasiūlè ir labai racionalų bendradarbiavimo principą - problemas paversti privalumais. Lietuvos bandymai sulaukè teigiamos Rusijos reakcijos. Dar 1998 m. Maskva neprieštaravo Karaliaučiaus srities įtraukimui į Baltijos jūros valstybių tarybos (BJVT) darbotvarkę bei į ES Šiaurès matmens iniciatyvą. Ją taip pat iliustravo ne tik regioninio bendradarbiavimo institucionalizavimas, bet ir bendri Vilniaus Maskvos siūlymai, svarbūs ES plètrai, igavę tarptautinị pavadinimą „Nidos iniciatyva“. Lietuvos pastangas atverti Kaliningradą teigiamai ịvertino ir patys kaliningradiečiai. Juolab kad 1999 m. spalio mèn. tuometinis Rusijos premjeras V. Putin asmeniškai išsakè savo nuomonę apie besiklostančią padètį, paskelbdamas apie galimybę transformuoti sritị i pilotinị eksperimentinị regioną santykiuose su ES,

${ }^{45}$ Kargopolov, Gorodilov, Kulikov, Gomin, (note 37) p. 67; Clopeckij, Fiodorov, (note 39) p. 41.

${ }^{46}$ Kargopolov, Gorodilov, Kulikov, Gomin, (note 37) p. 9.

${ }^{47}$ Gorodilov, Kozlov, (note 41) p. 61.

${ }^{48}$ Kargopolov, Gorodilov , Kulikov, Gomin, (note 37) p. 9, 138. 
taip pat pasirašyti su ES specialią sutartị, užtikrinančią srities, kaip Rusijos Federacijos subjekto, interesų apsaugą ${ }^{49}$.

Nors pilotinio regiono idejja nebuvo plètojama, būtent tada Kaliningrade kilo pagyvejjimas, neva ši idèja vẻl atveria kelius suteikti sričiai specialų statusą. 1999 m. pab. - 2000 m. pr. Maskva lūkesčių neslopino, tačiau tai darẻ labai savotiškai - didindama politinę įtampą srityje.

Iš pradžių Rusijos NTV televizijos laidose, o po to straipsniuose centrinèje bei vietos spaudoje (ir net The New York Times puslapiuose) pasirodè kritikos lavina srities gubernatorius L. Gorbenko atžvilgiu: argumentuoti kaltinimai korupcija, ryšiais su nusikalstamu pasauliu, kontrabandos skatinimu, kriminaliniais pačios gubernatoriaus šeimos siautėjimais. $\mathrm{O}$ iš Maskvos atvažiavę aukšti pareigūnai (pavyzdžiui, Užsienio reikalų viceministras Ivan Ivanov) atvirai reikšdavo nepasitenkinimą ne tik regionine autarkija, bet ir tuo, kad gubernatorius nieko konkretaus negali atsakyti į klausimą, kokius planus srities administracija puoselèja ES Šiaurès matmens atžvilgiu ir kaip ruošiasi tapti pilotiniu regionu ${ }^{50}$.

Tuo pačiu metu laikraščių puslapiuose pasirode informacija apie tai, kad Maskvoje brandinamas Kaliningrado srities teritorinio statuso įstatymas. Jame ne tik numatoma dar kartą formaliai patvirtinti ypatingosios ekonominès zonos egzistavimą srityje, bet drauge ịvesti ir federalini - tiesioginị valdymą. O tai reiškia, jog gubernatorius nebus renkamas - jị skirs Kremlius. Pasklido ir konkrečios galimo ịpėdinio pavardès gandai - dimisijos kontradmirolas, pirmasis Sankt Peterburgo vicegubernatorius Vladimir Grišanov ${ }^{51}$. Taigi jūreivis, kaip ir L. Gorbenko.

Situaciją paaiškino pats L. Gorbenko, beje, po susitikimų Kremliuje. Maskvoje svarstoma Rusijos teritorine administracinè reforma, numatanti padalinti šalies teritoriją i septynias federalines apygardas: Kaliningradas bus priskirtas Centriniam, o gubernatoriaus rinkimai ivvyks planuotu laiku $-2000 \mathrm{~m}$. rudenị.

Prezidentas V. Putin išleido ịsaką dèl teritorinès administracinès reformos gegužès mèn. Išvakarèse Rusijos televizijų žinių laidose buvo galima išvysti būsimą šalies politini žemèlapị: Karaliaučiaus sritis buvo nuspalvinta ta pačia spalva, kaip ir Centrinė federalinè apygarda. Spalvos pasikeite įsaką išleidus - sritis buvo priskirta Šiaurès Vakarų apygardai.

Gubernatoriaus rinkimai įvyko numatytu laiku - $2000 \mathrm{~m}$. spalio - lapkričio mèn. Du esminiai dalykai skyrè senojo ir naujojo pretendento - admirolo V. Jegorov - programas: V. Jegorov palankumą demonstratyviai rodè V. Putin; V. Jegorov ragino derinti srities (ir šalies) teisinę bazę su ES. Rinkimus laimėjo V. Jegorov ${ }^{52}$.

Admirolo pergalè vèl sužadino Kaliningrade viltis, kad sritis susilauks išskirtinio specialaus dèmesio. Apie tai tarsi bylojo tiek išorès, tiek vidaus faktai.

2000 m. lapkritį ES plètros strateginiame dokumente pirmą kartą oficialiai buvo nurodyta, kad Karaliaučius patirs ypatingą ES plètros įtaką. 2001 m. sausio mèn.

\footnotetext{
${ }^{49}$ Sirutavičius, Stanytė-Toločkiene, (note 13) p. 135; Kargopolov, Gorodilov, Kulikov, Gomin, (note 37) p. 134 - 135; Lopata, Laurinavičius, (note 20) p. 217, 221.

${ }^{50}$ Lopata, Laurinavičius, (note 20) p. 167.

${ }^{51}$ Ten pat, p. $166-167$.

${ }^{52}$ Ten pat, p. 217. İdomi detalè: po rinkimų L. Gorbenko gavo asmeninę prezidento dovaną vardinị laikrodị su užrašu „Už pasiekimus vystant Kaliningrado srities ekonomiką“.
} 
pasirodė Europos Komisijos komunikatas „ES ir Kaliningradas“, kuriame pabrezžiama, kad dèl unikalios geografinès padèties ES plètros poveikis sričiai gali būti didesnis, nei manyta iki tol. Vasario mèn. srityje apsilankẻ ES išorinių ryšių komisaras Chris Patten ir Švedijos Užsienio reikalų ministrè Anna Lindh, kovo mèn. - Lietuvos Prezidentas Valdas Adamkus. Apskritai per pirmuosius šešis mėnesius po gubernatoriaus rinkimų srityje pabuvojo delegacijos iš beveik visų Europos Sajungos valstybių, o pats gubernatorius buvo nuolatinis Rusijos oficialių delegacijų ES valstybėse narys.

Maskvoje V. Jegorov nesunkiai ǐssprendè koliziją, kurią sukẻlè Rusijos prekybos komiteto sprendimas, naikinantis ypatingosios ekonominès zonos lengvatas. Iš Prezidento bei premjero M. Kasjanov buvo gautas patikinimas, kad Maskva peržiūrès sprendimą dẻl srities priskyrimo federalinei apygardai, galbūt suteikdama jai aštuntosios federalinès apygardos statusą, keli srities vicegubernatoriai bus įtraukti i darbo grupę, atsakingą už ES plètros Rusijai pasekmių studiją, o Kaliningrado politikams teks ypatingas vaidmuo ruošiant Rusijos ir ES specialų susitarimą dèl Kaliningrado srities ${ }^{53}$.

Tačiau pažadai palaipsniui pradejo bliūkšti.

Rusijos vyriausybei $2001 \mathrm{~m}$. kovo mèn. 22 d. svarstant priemonių planą dèl Kaliningrado srities socialinio ekonominio vystymosi bei gyvybingumo užtikrinimo, M. Kasjanov garsiai, panašiai kaip 1996 m. V. Šumeiko, pareiškè, kad regionas taps „rinkos metodų taikymo pavyzdžiu“" ${ }^{4}$. Bet plane iš esmès buvo numatytos tik priemonès, kurios turejo padèti Maskvai išplèsti savos kompetencijos ribas ${ }^{55}$.

Liepos 26 d. Rusijos Federacijos Saugumo Tarybos posėdyje jau V. Putin ragino kiek galima greičiau neigiamus Kaliningradui ES plètros veiksnius paversti teigiamais ir greičiau apsispręsti dèl German Gref paruoštos „Federalinès tikslinès Kaliningrado srities socialinès ekonominès raidos 2002-2010 m." programos. Programa, kuriai finansuoti trūksta beveik $50 \%$ lèšų, buvo patvirtinta tik gruodyje. O posėdyje buvo nutarta ịsteigti Prezidento ịgaliotinio Šiaurès Vakarų federalineje apygardoje Viktor Čerkesov pavaduotojo pareigybę. Pavaduotoju paskirtas Andrej Stepanov tapo atsakingas už federalinių institucijų veiklos Kaliningrade koordinavimą ir turèjo užtikrinti Maskvos įtaką (kontrolę) srityje ${ }^{56}$.

Daugiau kaip metus Karaliaučiaus politikai plušèjo, ruošdami Rusijos - ES sutarties dèl Kaliningrado srities koncepciją bei patị sutarties tekstą. Beje, nesulaukdami pilotinio regiono idejjos išskleidimo centre, kaliningradiečiai pateikè ir savają bendradarbiavimo regiono idẻją ${ }^{57}$. Tačiau $2002 \mathrm{~m}$. kovo 4-5 d. Rusijos užsienio reikalų ministras Igor Ivanov, kalbėdamas BJVT IX sesijoje Svetlogorske, pareišké, kad tokios sutarties pasirašymas nèra tikslingas ${ }^{58}$.

${ }^{53}$ Lopata, Laurinavičius, (note 20) p. 231; Holtom, (note 8) p. 45-46.

${ }^{54}$ Holtom, (note 8) p. 47.

${ }^{55}$ Sirutavičius, Stanytė-Taločkienè, (note 13$)$ p. 178.

${ }^{56}$ Lopata, Laurinavičius, (note 20) p. 257.

${ }^{57}$ Chlopeckij, Fiodorv, (note 39) p. 316; Klemešev A., Kozlov S., Fiodorov G. Ostrov sotrudnichest$v a$, Kaliningrad, 2002, p. 155-156, 162-167. Iš esmès po „bendradarbiavimo regionu“ véliava maskuojamos pastangos išsaugoti ypatingosios ekonominès zonos privilegijas, užsitikrinti srities išskirtinumą, tiksliai apibrèžiant centro - regiono santykius, „legitimuoti“ ES standartus ekonomineje veikloje, tapti ne tik Rusijos Federacijos, bet ir ES ekonominès veiklos subjektu.

${ }^{58}$ Songal A., The Fate of the Exclave Decided (Manuscript), Kaliningrad, 2002, p. 2. 
Pagaliau ịsibėgèjus ir artėjant prie finišo Lietuvos ir Lenkijos deryboms dèl narystės ES, Maskva ịtraukẻ Kaliningradą į vadinamų techninių ir procedūrinių dalykų svarstymą ir ypač i̇ daugiausia rezonanso sulaukusį Rusijos piliečių tranzito per Lietuvos teritoriją i / /ǐ Karaliaučiaus srities klausimą.

Iki $2001 \mathrm{~m}$. pavasario Rusija iš ES reikalavo išlaikyti bevizị kaliningradiečių gyventojų keliavimo ị kaimynines valstybes režimą. $2001 \mathrm{~m}$. kovo 6 d. Maskva pakeitė poziciją, prašydama Kaliningrado gyventojams išduoti nemokamas vienų metų trukmès vizas, leidžiančias ịvažiuoti ị kaimyninių valstybių teritorijas, o po keliụ savaičiu pareikalavo koridoriaus metropolijos gyventojams, vykstantiems ị eksklavą per kaimynines valstybes. Kai tarptautiniuose forumuose srities gubernatorius vis aštriau reikšdavo susirūpinimą, kad vizų režimo atsiradimas taps pirmaja skiriamaja linija, paversiančia regioną dideliu rezervatu Europos viduje, Rusijos Užsienio reikalų ministerijos atstovai aiškino, kad vizų įvedinimas Karaliaučiaus gyventojams nebus skausmingas ${ }^{59} .2002 \mathrm{~m}$. audringai besiplètojusi vadinamoji bevizio tranzito ị Kaliningrado sritį byla dar labiau išryškino, kad Maskvai daugiau rūpi metropolijos, o ne regiono interesai ${ }^{60}$. Beje, federalinis centras to net neslëpè. $2002 \mathrm{~m}$. vasarą per Prezidento V. Adamkaus ir gubernatoriaus V. Jegorov susitikimą Palangoje Lietuvos pusé pristatė vadinamų magnetinių identifikacijos kortelių variantą, leisiantį moderniomis priemonėmis užtikrinti sklandžią eksklavo - kaimyninès valstybės sienos kirtimo procedūrą. Rusijos Užsienio reikalų ministerijos atstovų reakcija buvo tiesmukiška: „Mums reikia ne kortelių, o koridoriu“.

Šiame kontekste neturètų stebinti Karaliaučiaus politinio elito reakcija. Srities Dūmoje vietos politikai buvo priversti priiminèti rezoliucijas, reikalaujančias keleivių tranzito klausimą sieti su Rusijos - Lietuvos sienos sutarties ratifikacija Valstybès Dūmoje, laikraščių ar vadovèlių (sic!) puslapiuose jie atvirai reiškẻ nusivylimą, jog vykstančios derybos dèl tranzito nesprendžia gelminių srities raidos problemų. Kaip teigia srities Dūmos vicepirmininkas Sergej Kozlov, tai ne tik didina gyventojų netikrumą bei nepasitikèjimą federaliniu centru, bet ir dar sykị išryškina tendencijas, leidžiančias įvardinti regiono raidą kaip kvazikolonijinę: sritis - Rusijos Federacijos subjektas, kuriame dominuoja kariškių ir kitų federalinių jegos struktūrų įtaka ir kuriam nepaliekama alternatyvu igyvendinant metropolijos ekonominius, politinius ir karinius interesus ${ }^{61}$.

Turint omenyje ir šias nuostatas, lieka mažai abejonių, kad po priimtų sprendimų dèl keleivių tranzito 2003 m. vasarą išaugęs Maskvos dèmesys Kaliningrado sričiai ${ }^{62}$ (raginimai, skatinantys rengti naują „Ypatingos ekonominès zonos įstatymą“, V. Putin apsilankymas Kaliningrade ir pažadai imtis ekonominès regiono plètros problemų) - ne kas kita, o tik mėginimai užtikrinti tolimesnị ịkaito mechanizmo funkcionavimą.

\footnotetext{
${ }^{59}$ Rusijos Federacijos URM atstovo Kaliningrado srityje ambasadoriaus A. Kuznecov pareiškimas, Baltic News Service, 2001 m. kovo 26 d.

${ }^{60}$ Sirutavičius, Stanytė-Taločkienè, (note 13) p. 191-195.

${ }^{61}$ Gorodilov, Kozlov, (note 41) p. 64.

${ }^{62}$ Stanyté-Toločkienè I., „Kaliningrado ateitis - Maskvos rankose“, Lietuvos Rytas, 2003 m. liepos

$5 \mathrm{~d}$.
} 


\section{Išvados}

Atliktas tyrimas patvirtino versiją, kad Maskva (metropolija, federalinis centras), siekdama išsaugoti suverenitetą, užtikrinti ryši su Kaliningrado (Karaliaučiaus) sritimi, šią eksklavinę provinciją pavertė geopolitiniu ịkaitu.

Konkrečiomis Kremliaus vykdytomis užsienio politikos priemonėmis buvo pasiekta, kad sritis didžiojoje politikoje Rusijos - Vakarų santykiams kelia nemažą problemą.

Akivaizdu, jog problemos aštrumas priklausė nuo Maskvos gebẻjimo manipuliuoti Rusijos padėtị veikusiais išorès bei vidaus veiksniais. Reikia pripažinti, kad tam tikrais atvejais šiais veiksniais metropolija naudojosi gana sẻkmingai. Vakarai iš esmès neišdrịso priminti komplikuotų politinių ir teisinių Kaliningrado (Karaliaučiaus) srities statuso aspektų ir dažniausiai būdavo linkę politinę problemą spręsti techniniais būdais. Tai atvėrẻ Kremliui rankas naudoti spaudimą kaimyninių, eksklavą supančių valstybių, atžvilgiu, sunkinti jų ir euroatlantinių institucijų dialogą. Kita vertus, tai tapo palankia dirva Maskvai manipuliuoti tariamu Kaliningrado (Karaliaučiaus) eksklavo at(si)vėrimu išorinei aplinkai, praktikoje neleidžiant reikštis visuotinai pripažįstamai jo specifikai. Tačiau iki šiol nėra aišku, ar naudojantis tokiu geopolitinio ịkaito mechanizmu metropolijai pavyks sẻkmingai palaikyti eksklave Stokholmo sindromą. 